\title{
Flip sides of exploration
}

\author{
Aerial photos taken during a 1930s expedition to the southeastern Greenland margin had been classified \\ and lost to science. Their rediscovery highlights how closely geopolitical and scientific ambitions are \\ linked in exploration.
}

Filed away and long forgotten in a Danish citadel, the aerial photos from two expeditions to east Greenland in the 1930s had been awaiting rediscovery. The east coast of Greenland had flummoxed many previous attempts at exploration due to severe ice conditions that made approach by ship difficult ${ }^{1}$. Equipped with the latest photographic and aircraft technology supplied by the Danish navy, and led by an experienced Arctic explorer, the expeditions successfully surveyed the treacherous coastline. Eighty years later, the photographs have been brought back to life by Anders Bjørk and colleagues, who provide a historical window into the waxing and waning of southeast Greenland's glaciers on page 427 of this issue.

The expeditions were led by the legendary explorer Knud Rasmussen (1879-1933). He was Danish, but was born in Greenland and spent his early boyhood there. Rasmussen is perhaps most famous for his Fifth Thule Expedition, during which he traversed across Arctic Canada to Alaska, and became the first European to cross the Northwest Passage by dog-sled. Rasmussen was initially more interested in anthropology than in glaciology, and had devoted the bulk of his previous expeditions to the study of native Eskimo groups across the Arctic. No doubt many ethnographic questions remained to be solved in 1931, yet his attention shifted to the mostly uninhabited east coast of Greenland, and to precisely recording the condition of the ice margin there.

The reason is at least partially rooted in politics. At the time, Denmark and Norway were in the midst of a dispute over east Greenland. Though the whole of Greenland had been claimed by Denmark, Norway declared a portion of eastern Greenland as its territory in 1931. The dispute motivated the Sixth and Seventh Thule Expeditions, which surveyed the southeastern margin of Greenland before Denmark's victory in a judgment at the international court in the Hague in 1933. Rasmussen himself was deeply involved in the geopolitical situation. He supported a united Greenland

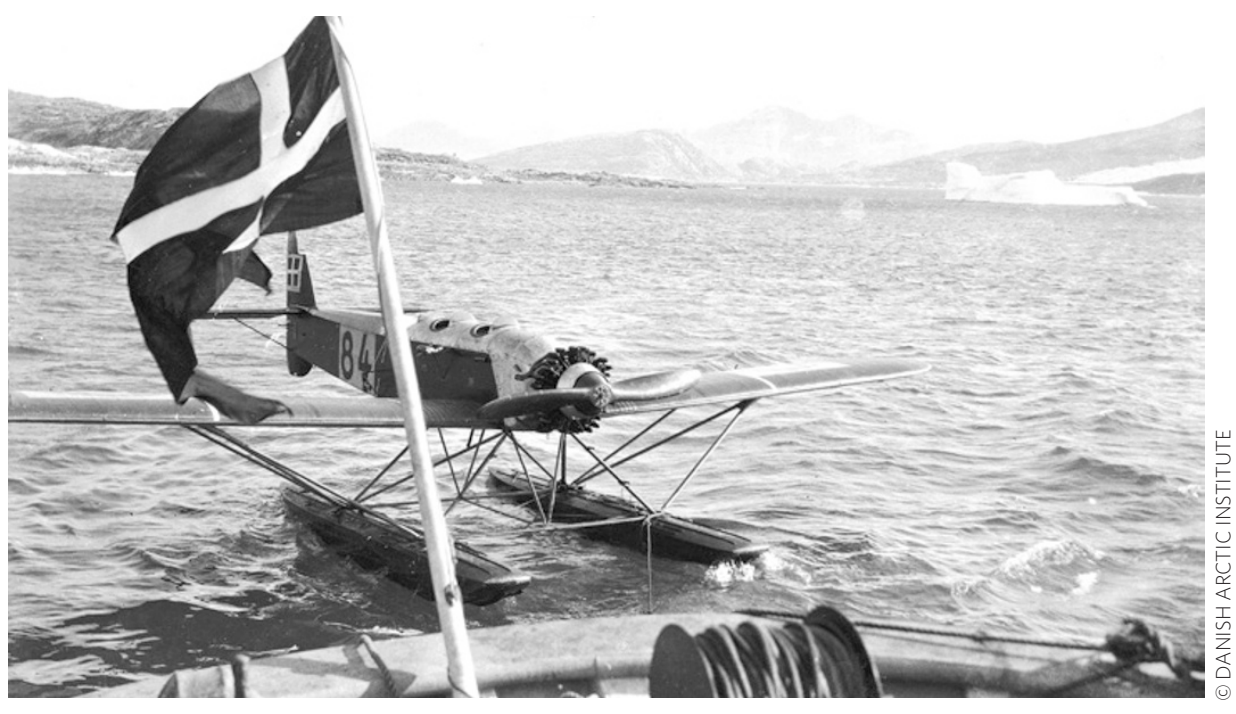

under Denmark's reign, and moved from researching Greenland's folklore to surveying efforts ${ }^{1}$.

Today, the polar regions are once again under a geopolitical spotlight. In the Arctic, currently closed ocean passages are expected to become navigable by ships, as sea ice retreats in a warming climate ${ }^{2}$. The new accessibility is leading to a rush north, to assert national presence in the Arctic - ultimately to gain control over emerging trading routes as they open. The geopolitical situation provides a strong incentive for governments to fund surveys and environmental impact studies in the Arctic.

At the South Pole, research and exploration are not free from overtones of territorial interest either - despite the 1961 Antarctic Treaty, which sets the continent aside for science ${ }^{3}$. At both ends of the world, polar science - essential to understand the impacts of climate change - ultimately benefits from the political ambitions in these areas.

The interests of politicians are not always well aligned with those of the scientific community. But some of the most spectacular leaps forward in science have come about with a good dose of support from global politics. For example, scientific discoveries continue to come from images and lunar samples brought back from the Apollo missions, long after the end of the Cold War and the space race between the Soviet Union and the United States ${ }^{4}$.

Without the political tension over territorial claims in east Greenland, the Sixth and Seventh Thule expeditions to southeast Greenland would probably not have taken place. But despite the political motivation of the surveys, the expedition team fully recognised the scientific value of their aerial photographs. In his paper about the expeditions, secondin-command Captain Gabel-Jørgensen wrote that "the instantaneous record [...] of the present state of the glaciers of the entire coast is in itself of great value to future researchers" . That value is finally being realised.

Geopolitical disputes can lead to the release of funds for exploration, with potentially impressive benefits to science. Perhaps scientists could do worse than paying a visit to their local citadels.

\footnotetext{
References

1. Gabel-Jørgensen, C. C. A. Geogr. J. 86, 32-49 (1935)

2. Stephenson, S. R. et al. Nature Clim. Change 1, 156-160 (2011)

3. Naylor, S. et al. Nature Geosci. 1, 143-145 (2008).

4. Editorial. Nature Geosci. 4, 69 (2011)
} 